\title{
State support of agriculture in Ukraine: innovation and investment aspects Volodymyr Halanets ${ }^{1}$, Yurii Dziurakh ${ }^{2}$ \\ 1. Administrative and Financial Management Department, Lviv Polytechnic National University, UKRAINE, Lviv, S. Bandery street 12, E-mail: volodymyr.v.halanets@lpnu.ua \\ 2. Administrative and Financial Management Department, Lviv Polytechnic National University, UKRAINE, Lviv, \\ S. Bandery street 12, E-mail: yriu.dziurakh@ukr.net
}

\begin{abstract}
The analysis of the current state of state support of innovation and investment development of Ukrainian agribusiness complex is carried out. The problematic aspects that hinder the development of domestic agricultural enterprises and emphasize the need for the introduction of innovative technologies have been identified. The investment attractiveness of innovative technologies and machinery of agroindustrial complex is low due to the unstable situation in the country and the imperfect legislative framework. It is proved that innovation and investment development is the only real basis of socio-economic transformations in the agro-industrial sector and the emergence of a new trajectory of development and competitiveness of the national product in world markets.
\end{abstract}

Key words - state support; agriculture, innovation, investment,governance, state financing.

\section{Introduction}

The agro-industrial complex is an integral part of Ukraine's economy, which provides socio-economic development, food security, living standards and raw materials for industry. In order to ensure sustainable development and competitiveness of the agrarian sector, Ukraine must establish a progressive and efficient mechanism for managing agro-industry production based on investments and innovations. According to international practice, the main scientific developments, research and projects are funded and regulated by the state, resulting in rapid economic growth, social impact, avoidance of negative side effects in economic policy, etc.

\section{Presenting main material}

The comparison of the efficiency of the Ukrainian agroindustrial complex in the agroindustrial complex of other European countries confirms the availability of unused huge resources and trends, the processing of which, with appropriate state support, can stimulate agrarians to enter the leading food-producing producers of the world [1, p. 49].

Ukrainian agriculture, in comparison with many foreign countries, has natural advantages, owning $8.7 \%$ of the world's black earth reserves; $2.2 \%$ of the world's grazed area. The agrarian sector provides food security and food independence of the state, produces $12 \%$ of Ukrainian GDP, creates jobs for the employed population (17\%), the agrarian sector covers about $60 \%$ of the population's consumption fund [2, p.37]

Innovation-investment activity in the agroindustrial complex is associated with the investment of existing and the search for additional financial resources, attracting investment in the development and implementation of innovative technologies in the development of the agroindustrial complex.

Today, the innovation potential is in partly used. The main innovators in the agroindustrial complex are usually large scientific institutions, which are separated from agricultural producers. The absence of a clear, well-founded organizational and economic mechanism for transferring the achievements of science to agricultural commodity producers leads to a significant backlog of the industry for the development of innovations in production [3, p. 16]. The experience of developed countries shows that the increase in the efficiency of agro-industrial production is achieved mainly due to the intensification of innovation activity, the successful functioning of the 
scientific and technical sector of the industry. The ultimate result of innovation is the creation of innovations and their development directly in production, which contributes to the systematic organizational, economic, technological and technological rehabilitation of agricultural production and increase its efficiency [4, p. 81].

In Ukraine, innovative shifts in the agrarian sector are significantly hampered by factors such as: low commercialization of agrarian science, imperfection of innovation infrastructure in the agro-industrial complex, underdeveloped agrarian technology transfer processes, etc.

The current low activity of innovation activity in the agroindustrial complex is due to the imperfection of the organizational and economic mechanism of development of innovations.

A significant factor hindering the innovative development and investment attractiveness of Ukraine is the lack of an appropriate legislative and regulatory framework for regulating innovation and investment activity, strengthening control functions for their implementation.

The state of state support for farmers in Ukraine shows that there is an imperfect and nontransparent mechanism for selection of enterprises for compensation of compensations and subsidies; as a result, these types of support do not encourage owners to invest their own funds and invest in innovative technologies and technology, which reduces the cost of production and increases it's efficiency. Also, the question of pricing is unresolved, since the situation in the country remains unchanged, when the producer is losing incomes, large enterprises by reselling have profits.

In 2015, NAAS together with the Ministry of Agrarian Policy within the framework of a single integrated Strategy for Agricultural and Rural Development for the period of 2015-2025 developed a draft Concept for the reform of agrarian science based on an innovation model [5]. The project is still under discussion.

The current agro-industrial complex is characterized by a high level of risk of innovation processes: the risk of financing research and production results, the uncertainty of demand for innovative products, the risk of a temporary gap between costs and results, etc. The assessment of the situation in the agroindustrial complex shows that activation of innovation activity without realization of the system of measures of financial rehabilitation and phased restoration of production becomes practically impossible.

In accordance with the Law of Ukraine "On the State Budget of Ukraine for 2018" [6], the Ministry of Agrarian Policy and Food of Ukraine allocated expenditures of UAH 14.1 billion to finance expenditures, of which UAH 6311.0 billion were allocated for agricultural development programs. For comparison, in 2017, 7.4 billion UAH was allocated to the Ministry, in the direction of the agroindustrial complex - 5.5 billion UAH.

The bulk of the funds put into the state budget in support of the agroindustrial complex in 2018 (UAH 4 billion or $28.3 \%$ of all resources) is aimed at supporting livestock production. In the second place in terms of financing - support for farming - in this direction allocated 1 billion. (7.1\% of the total). For farmers there is another separate program "Granting loans to farms", for its implementation allocated 43 million UAH; for the program "Financial support of agricultural producers" was laid 945 million UAH. (6.7\% of the total funding for 2018) [6].

Main directions of state support to the agrarian sector for 2018 is Programm "State support for stockbreeding". The right to receive funds under this state program has:

1. Producers who build or reconstruct livestock complexes. This program will be directed to 2.5 billion $\mathrm{UAH}$, but it provides:

- $25 \%$ compensation of the loan body involved in the construction or reconstruction of 
complexes in the sectors of pig, poultry and cattle. The effective rate of these loans will be about $3 \%$ in UAH up to 5 years.

- 30\% reimbursement of the cost of putting into operation livestock systems built without borrowing funds if not involved credit resources.

$-3 \%$ reduction in the cost of credit resources involved in projects for the development of aquaculture, sheep breeding, cowsheds.

2. Farmers who keep milk cows.

The volume of this state support is $500 \mathrm{mln}$. This support can be obtained by virtually all legal entities. Agricultural enterprises compensate UAH 1,500 per dairy cow per year. (compensation of the cost of maintaining milk production cows available as of 01.01.2018 and 01.07.2018).

3. Farmers who buy breeding stock

The volume of this state support to agricultural enterprises amounts to UAH 300 million and provides for:

$-50 \%$ compensation for the cost of high-yielding stock, as well as biological material and embryos.

4. Citizens (physical persons) keeping young animals of cattle

The volume of this state support is 700 million UAH. This support can be obtained from private households. in which people themselves grow cattle and keep at least 12 months young cattle. Compensation for a household will be made for each head of such cattle per year in the amount of 2500,00 UAH.

Today, Ukraine is actively considering the possibilities of integration with the markets of the European Union. First and foremost, it provides for the creation of conditions for activation of investments into the agricultural sector, ensuring free movement of funds, developing the financial services market, introducing modern technologies and European social standards of living in rural areas. The state has to move first of all in the direction of reproduction of normal conditions for an entrepreneur. Such conditions that would enable an effective lucrative business.

The tendencies of austerity towards the Ukrainian market are still due to the rather difficult economic and political situation. Especially high interest in the implementation of investment projects in Ukraine today is not observed. Everyone thinks that this is an important market that is developing, but unfortunately, the arrival of serious international players is not evident, which certainly affects the amount of funding that the EBRD can offer. At the same time, the bank relied on the market demand and how much the Ukrainian companies are willing to raise funds.

Activation of investment activity is not only the main condition for the withdrawal of agriculture from the deep crisis, but also becomes the most important determinant of its further development. It is necessary not only to reform the social structure in the countryside through institutional reforms, which was a prerequisite for the initial period of agrarian reform, but also the attraction of large-scale investments into the agricultural sector, which is a pressing need for virtually all branches of agro-industrial complex. The formation of prerequisites for a mass influx of investment in the agrarian sector should become an important element of the state policy strategy for agrarian policy at the present stage.

It should be noted that such important articles for the development of agroindustrial complex as research, applied scientific and scientific and technical developments, works on state target programs and government orders in the field of development of the agro-industrial complex, training of scientific personnel, scientific developments in the field of standardization 
and certification of agricultural products, research and experimental development in the field of agro-industrial complex, make up only $1 \%$ of the budget of the agro-industrial complex.

An important issue is the formation of a state innovation and investment policy, which should determine the objects of support of the innovative environment and create a favorable investment climate. Currently, the state must provide continuous support to the agrarian sector of the economy, which will allow not only to provide the population with high-quality agricultural products, raw materials and food of domestic production, but also to export it, thus forming the food security of the country.

\section{Conclusion}

The current state of state support to the agricultural sector needs considerable improvement and support. The size of compensations and subsidies do not meet the requirements of the present, do not create conditions for the introduction of innovative technologies in the agroindustrial complex and the development of agriculture.

The state administration of the agroindustrial complex needs to carry out a number of effective reforms, which will contain a series of interconnected and structured measures for efficient and effective support of this direction. However, it should be noted that reforms will have an economic effect only with the definition of clear deadlines for implementation, responsible persons, control system and punishment.

Only permanent state support for the development of innovation and investment activities can ensure the dynamic development of the industry. The main condition should be the continuous updating of technologies and widespread use of the latest scientific developments. The way out of agriculture from a crisis situation is to develop its innovative basis by increasing the technical and economic level of production and as a result of improving the investment climate.

\section{References.}

[1] Kushnir, S. O. (2017), "State support for agro-industrial complex", Ukrainskyi zhurnal prykladnoi ekonomiky, vol. 2, issue 1, pp. 48-56.

[2] Ukrainskyi instytut naukovo-tekhnichnoi ekspertyzy ta informatsii (2017), "Analytical Reference: Status of Innovation and Technology Transfer Activities in Ukraine in 2016", Kyiv, Ukraine, p. 130.

[3] Ilchuk, V. Derkach, A. and Pchelnikova, K. (2017), "Innovative investment and investment activity of industrial enterprises of Ukraine", Problemy $i$ perspektyvy ekonomiky ta upravlinnia, vol. 2, pp. 15-21

[4] Zhydiak, O. R. (2013), "State support of innovative activity of enterprises of agrarian sphere", Innovatsiina ekonomika, vol. 1, p. 80-83, available at: http://nbuv.gov.ua/jpdf/inek_2013_1_22.pdf.

[5] Cabinet of Ministers of Ukraine (2011), Decree of the Cabinet of Ministers of Ukraine " On Approval of the Concept of Reform and Development of Agrarian Education and Science", available at: http://zakon3.rada.gov.ua/laws/show/279-2011-\%D1\%80.

[6] The Verkhovna Rada of Ukraine, The Law of Ukraine " On the State Budget of Ukraine for 2018", available at: http://zakon5.rada.gov.ua/laws/show/2246-19. 